\title{
Kardiyak resenkronizasyon tedavisinde sol ventrikül elektrodu implantasyon teknikleri
}

\author{
Implantation techniques of left ventricular pacing electrode for cardiac \\ resynchronization therapy
}

Osman Beton*, İzzet Tandoğan

Kardiyoloji Kliniği (Dr. O. Beton), Dışkapı Yıldırım Beyazıt Eğitim ve Araştırma Hastanesi, TR06330 Ankara, Kardiyoloji Kliniği (Prof. Dr. İ. Tandoğan), Özel Gözde Hastanesi, TR-44100 Malatya

\section{Özet}

Kardiyak resenkronizasyon tedavisi, sol ventrikül elektrodunun arzu edilen lokalizasyona yerleştirilmesi ile mümkün olur. Sol ventrikül elektrodu günümüzde sıklıkla koroner sinüs kanulasyonu yolu ile hedef sol ventrikül bölgesinden köken alan koroner sinüs dalına yerleştirme prensibine dayalı perkütan transvenöz yöntemler ile yapılmaktadır. Sol ventrikül elektrodunun, koroner sinüste hedef dala başarılı bir şekilde yerleştirmek için birçok implantasyon tekniği geliştirlmiştir. Perkütan transvenöz yolun başarısız olduğu durumlarda alternatif implantasyon teknikleri uygulanmaktadır.

Anahtar sözcükler: Kardiyak resenkronizasyon tedavisi, sol ventrikül elektrodu, koroner sinüs, implantasyon teknikleri

\begin{abstract}
Cardiac resynchronization therapy is contingent when left ventricular pacing electrode is placed in desired optimal location. At the present, left ventricular pacing electrode is often placed in coronary sinus branch originating from the left ventricular target region via coronary sinus cannulation by techniques based on percutaneous transvenous methods. Numerous implantation techniques are available for successful implantation of left ventricular pacing electrode in target branch of coronary sinus. There is some alternative implantation techniques in case of failed percutaneous transvenous route.
\end{abstract}

Keywords: Cardiac resynchronization therapy, left ventricular pacing electrode, coronary sinus, implantation techniques

Geliş tarihi/Received: 05 Kasım 2014; Kabul tarihi/Accepted: 12 Aralık 2014

*İletişim adresi:

Dr. Osman Beton, Kardiyoloji Kliniği, Dışkapı Yıldırım Beyazıt Eğitim ve Araştırma Hastanesi, TR-06330 Ankara. E-posta: obeton@cumhuriyet.edu.tr

Giriş

Kardiyak resenkronizasyon tedavisi uygulanabilmesi için genellikle sol ventrikül elektrodu implantasyonu gerekmektedir. Günümüzde, direkt epikardiyal uyarıya (elektrodun cerrahi yerleştirilmesine) kıyasla daha az invaziv işlem olması nedeniyle, sol ventrikül elektrodu yerleştirilmesi işlemi için koroner venöz yaklaşım tercih edilmektedir. Optimal hemodinamik destek, arzu edilen ven lokalizasyonuna ulaşmak ve frenik sinir uyarısına neden olmadan yeterli pace parametreleri elde etmek, başarılı sol ventrikül elektrod implantasyonu işleminin en önemli bileşenleridir. Koroner venöz sistemin çok değişken anatomik yapısının yol açtı̆̆ zorluklara rağmen, tecrübeli ellerde koroner venöz sistem kanulasyon yolu ile sol ventrikül elektrod implantasyonu başarı oranı \%95 
üzerindedir [1-3]. Yüksek implantasyon başarı oranı elde edilmesi başta tecrübenin yanı sıra koroner venöz anatominin iyi bilinmesi, işlem öncesi veya sırasında koroner venöz sistemin iyi görüntülenmesi ve elde edilen görüntülere uygun koroner venöz sistem kanulasyonu için uygun kateter ve yöntem seçimine dayanmaktadır.

\section{Koroner sinüs anatomisi}

Kalp venlerinin çoğu koroner sinüse açılmaktadır (Şekil 1). Koroner sinüs, 3-4 cm uzunluğunda ve yaklaşık $10 \mathrm{~mm}$ genişliğinde bir venöz kanal yapısında olup, koroner sulkusun posterior kısmına yerleşik ve sol atriyum muskuler lifleri ile çevrilidir. İnferior vena kava ile atriyoventriküler bileşke arasında sağ atriyuma açılmaktadır. Ağız kısmını bir semilunar kapak olan Thebesian kapağı bulunmaktadır. Koroner sinüs distalde büyük kardiyak venin koroner sinüse döküldüğü bölgede sıklıkla ikinci bir kapak olan [1-3] kapakçıktan oluşan Vieussens kapak bulunmaktadır. Bu kapakların anjiografik olarak görüntülenmesi zordur (Şekil 2) [2, 4].

Koroner dallarından olan büyük kardiyak ven, atriyoventriküler olukta seyrederek koroner sinüse 180 derece açı ile dökülür. Koroner sinüse döküldüğü bölgede Vieussens kapak bulunmaktadır. Büyük kardiyak vene, posterior, posterior-lateral ve lateral kardiyak venler dökülebilir. Anterior interventriküler ven, anterior interventriküler oluğun alt veya orta üçtebirlik kısmından köken alarak kalbin bazaline kadar seyreder ve atriyoventriküler olukta arkaya dönerek büyük kardiyak vene dökülür. Orta kardiyak ven "middle cardiac vein", apekse yakın bölgeden köken alarak posterior interventriküler olukta seyreder ve koroner sinüse sağ atriuma açılma yerinden hemen önce dökülür. Varyant olarak direkt sağ atriyuma da açılabilir [2, 4] Büyük kardiyak venin, lateral ven ile orta kardiyak ven arasında kalan bölgesine sol ventrikülün posterior kısmından köken alan posterior ven ve sol ventrikülün posterior-lateral bölgeseinden köken alan posteriorlateral venler dökülebilir. Posterior ve posterior-lateral ven koroner sinüse de dökülebilir. Lateral venler "left marginal veins" sol ventrikülün lateral bölgesinden köken alır ve büyük kardiyak vene veya koroner sinüse dökülür $[2,4]$

Başarılı sol ventrikül elektrodu implantasyonu için koroner sinüs anatomisinin ve farklı projeksiyonlardan görüntülerinin iyi bilinmesi gerekmektedir (Şekil 3) [2, 4].

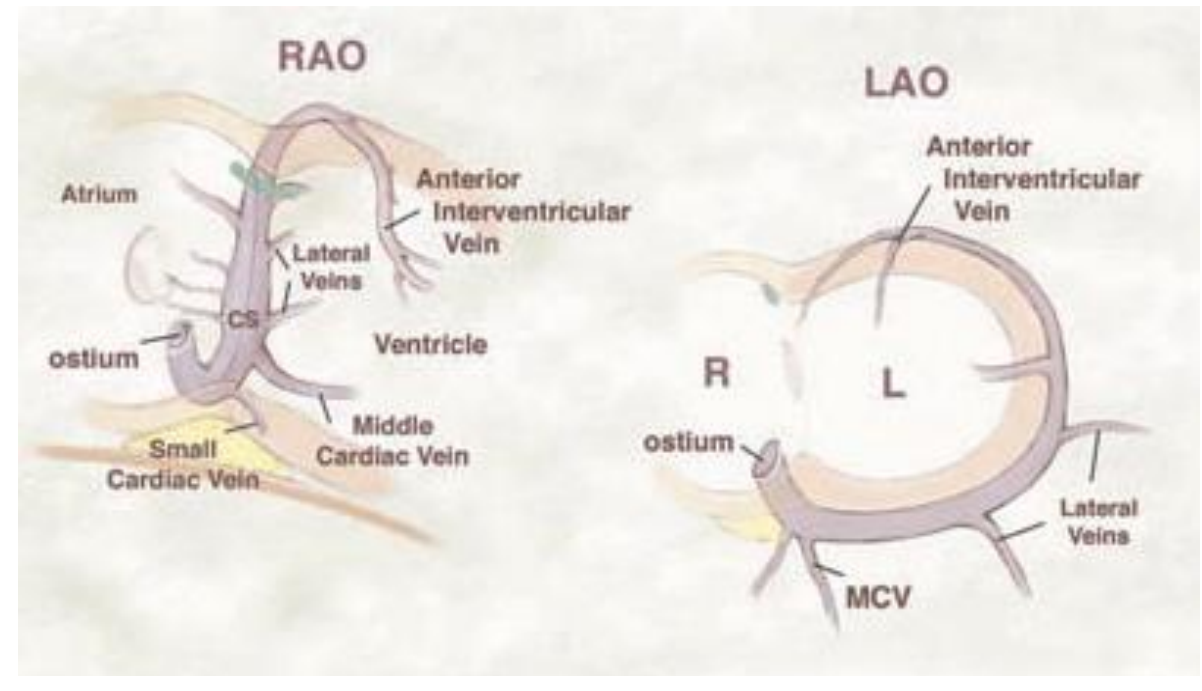

Şekil 1. Koroner sinüs ve ventriküler venler. Sağ anterior oblik pozisyonda (sol) ve sol anterior oblik pozisyonda (sağ) koroner sinüs ve ventriküler venöz dalları: Middle kardiyak ven, lateral venler (posterior ven ve posteriorlateral ven) ve anterior interventriküler ven izlenmektedir. 


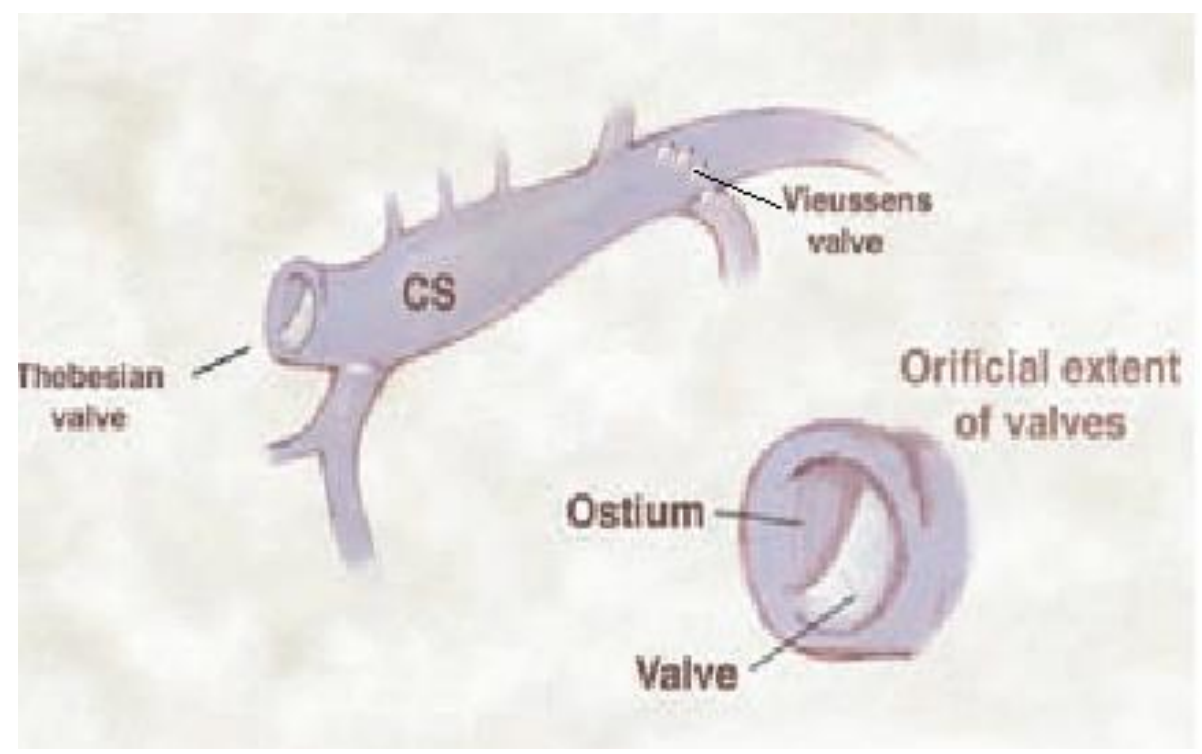

Şekil 2. Koroner venöz sistemdeki kapaklar.
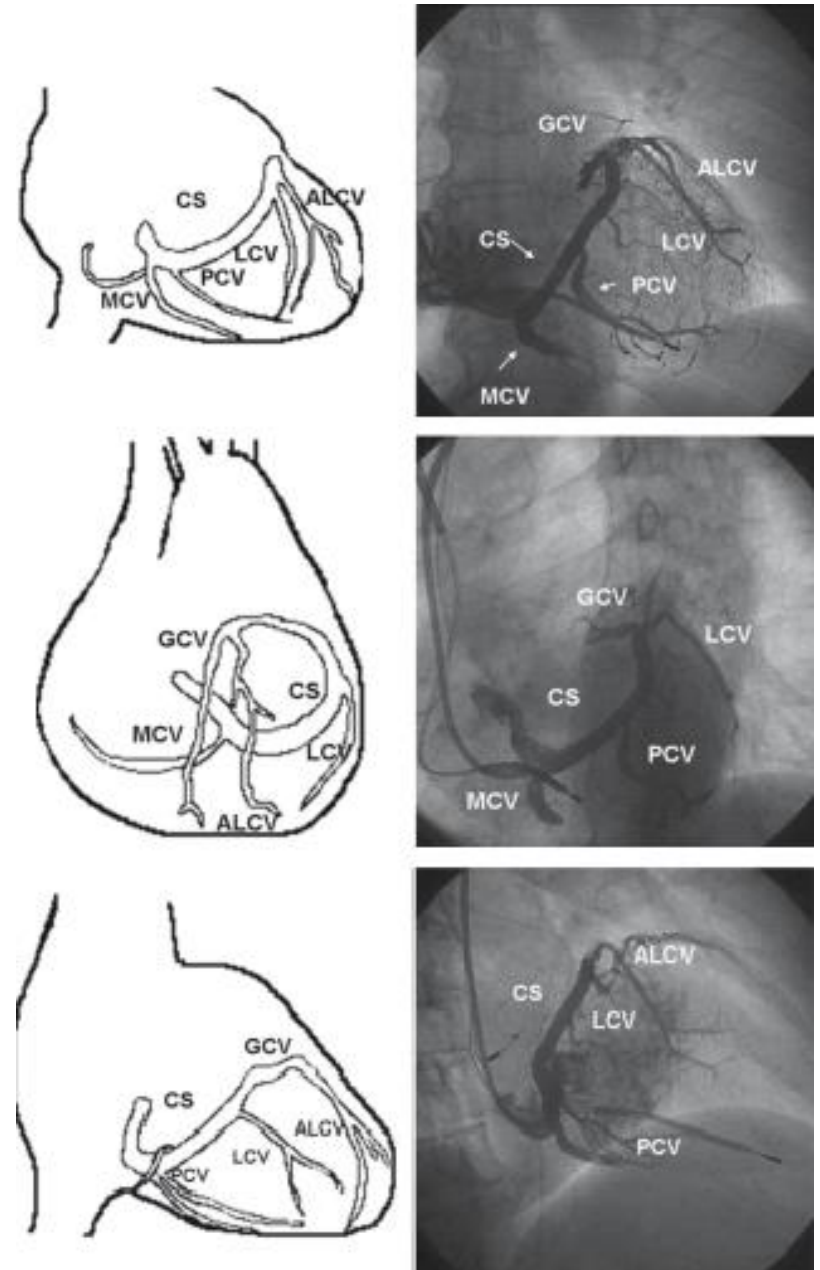

Şekil 3. Koroner sinüs venografik görüntüleri. Sol anterior oblik (üstte), anterior-posterior (ortada) ve sağ anterior oblik (altta) pozisyonlarda koroner sinüs venografik görüntüleri (sağda) ve aynı pozisyonlardaki anatomik şemaları (solda) izlenmektedir. ALCV: Anterior interventriküler ven; CS: Koroner sinüs; GCV: Büyük kardiyak ven; LCV: Lateral ven; MCV: Orta kardiyak ven; PCV: Posterior kardiyak ven. 


\section{Koroner sinüs kanülasyonu için malzeme seçimi}

Koroner sinüs kanülasyonu için seçilen malzemeler, sol ventrikül elektrodunun hedef koroner sinüs dalına yerleştirilmesinde büyük önem taşımaktadır. Sol ventrikül elektrodu, koroner sinüse yerleştirilen guiding kateter veya kılıf içerisinden ilerletilerek koroner sinüs hedef dalına yerleştirilir. Bu amaçla uzunluğu $45 \mathrm{~cm}$ ile $60 \mathrm{~cm}$ arası değişen birçok farklı guiding kateter veya kılıf geliştirilmiştir (Şekil 4) [1, 3, 4].

KRT tedavisi için koroner sinüs kanülasyonu sıklıkla sol subklavian ven yolu ile yapılmaktadır. Sağ subklavian ven ancak sol subklavian venin kullanılamadığı durumlarda seçilmektedir. Nedeni, her ne kadar sağ subklavian ven yolu için özel guiding kateterler geliştirilmiş olsa da, kanülasyon için kullanılan malzemeler sol subklavian yoldan koroner sinüsü daha kolay kanüle edebilmesidir $[1,3,4]$. Guiding kateterler, gerek normal hallerde gerekse patolojik durumlarda (koroner bypass sonras1, kapak ameliyat1 sonrası, vs) çok farklı varyasyonları gösteren koroner sinüsün ostiumuna ulaşmak için geliştirilmiştir [1, 3, 4].

Guiding kateterler tek başına koroner sinüsü kanüle edebilmektedir. Guiding kateterlerin tek başına koroner sinüsü kanüle edemediği durumlarda, guiding kateter içerisinden farklı özelliklerde koroner anjiyografi kateterleri (multipurpose, AL2, AL3, Hook, vs) veya elektrofizyoloji kateterleri (koroner sinüs kateterleri, deflektable koroner sinüs veya ablasyon kateterleri, vs) denenmekte ve koroner sinüse yerleşilmeye çalış1lmaktadır. Koroner sinüse yerleşildikten sonra mevcut kateter teleskopik olarak kullanılmakta ve üzerinden guiding kateter kaydırılarak koroner sinüse yerleştirilmektedir [1, 3, 4].
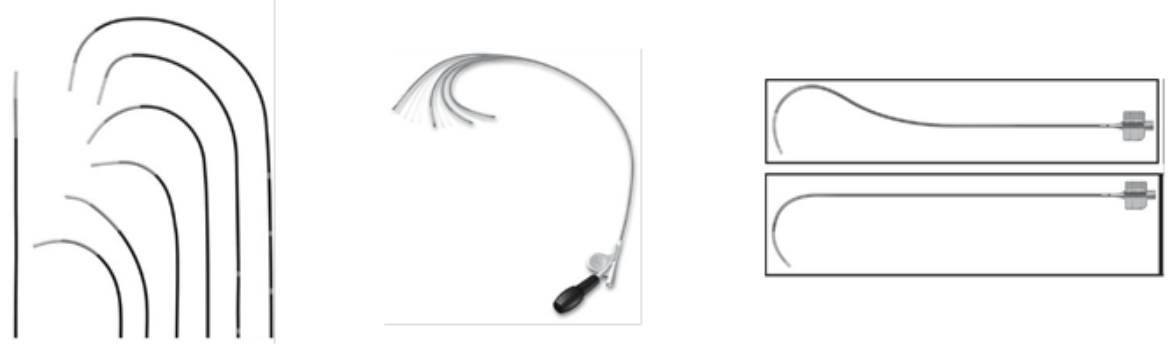

Şekil 4. Koroner sinüs kanülasyonu için kullanılan guiding kateterler. Sol subklavian venden koroner sinüs kanülasyonu için geliştirlmiş farklı açı ve kavislere sahip guiding kateterler (solda), ucu bükülebilir (deflectable) guiding kateter (ortada) ve să̆ subklavian yoldan koroner sinüs kalülasyonu için geliştirilmiş guiding kateterler (sağda).

Guiding kateter içerisinden sol ventrikül elektrodu yerleştirildikten sonra, guiding kateterler "peel-away" veya özel bıçakla yırtılabilir özellikleri ile sol ventrikül elektrodu yerinden oynatılmadan çıkartılmaktadır (Şekil 5) [1, 3, 4].
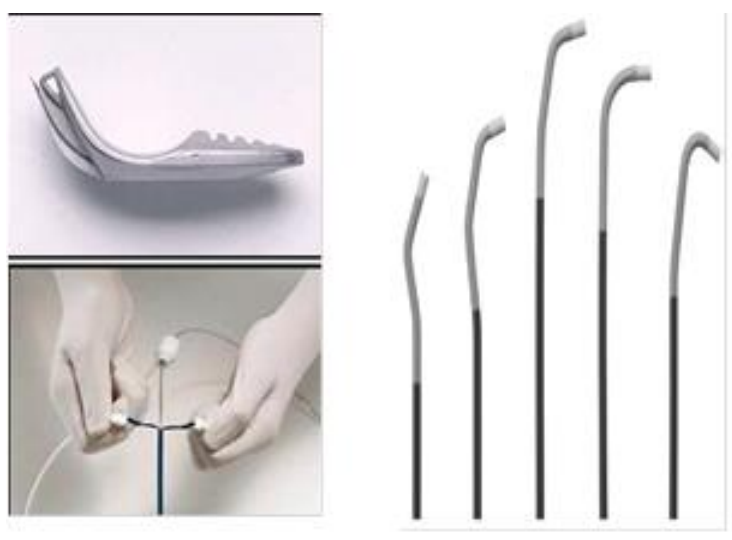

Şekil 5. Koroner sinüs kateterleri. Sol ventrikül elektrodu koroner sinüse yerleştirildikten sonra guiding kateter veya kılıf özel bıçakla (sol üstte) veya peel-away özelliği (sol altta) ile çıkartılmaktadır. Koroner sinüs sistemi içerisinde dallara yerleşmeyi sağlayan guiding kateter veya kılıf içerisinden ilerletilen iç (inner) kateterler (sağda) geliştirilmiştir. 


\section{Koroner sinüs kanülasyon teknikleri}

Koroner sinüs kanülasyonu, KRT cihaz implantasyonu işleminin en önemli fazıdır. Doğru koroner sinüs kanülasyonu ve guiding kateterin yeterli poziyona yerleştirilmesi, gerek koroner sinüs görüntülenmesinde gerekse sol ventrikül elektrodunun hedef dala yerleştirilmesinde büyük önem taşımaktadır. Koroner sinüs kanülasyonunda farklı teknikler bulunmaktadır $[1,3,4]$.

Subklavian ven ponksiyonu sonrası, guiding kateter veya kılıf tel üzerinden sağ atriyuma kadar ilerletilir. Sol anterior oblik poziyondan guiding kateter direkt koroner sinüse doğru yönlendirilerek koroner sinüs kanülasyonu yapılmaya çalışılır (Şekil 6). Vakaların bir kısmında, sağ atriyum büyüklüğüne ve daha önce yapılan görüntüleme yöntemleri ile saptanan koroner sinüs ağzının sağ atriyuma açılma açısı ve yönüne uygun seçilen guiding kateter veya kılıf ile direkt kanülasyon ihtimali oldukça yüksektir. Sol ventrikül elektrodu yerleştirilmesi için guiding kateter curve kısmının, büyük oranda koroner sinüs içerisine yerleştirilmesi gerekmektedir. Bu teknik ile bazen guiding kateter koroner sinüs ağız kısmında kapağa takılabilir. Bu durumda, guiding kateteri taşıyabilecek ucu düz bir tel (örneğin 0,035 inç. hidrofilik guidewire) koroner sinüs içerisine yerleştirilir. Guiding kateter bu tel üzerinden kaydırılarak koroner sinüse yerleştirilir [1, 3, 4].

Başlangıçta bükülebilen (deflectable) elektrofizyoloji kateteri kullanılması başka bir kanülasyon tekniğidir. Bu tekniğe aynı zamanda elektrofizyolog tekniği de denmektedir (Şekil 7). Sağ atriyuma yerleştirilen guiding kateter içerisine bükülebilen (deflectable) elektrofizyoloji kateteri yerleştirilir. Sol anterior oblik poziyonda elektrofizyoloji kateteri koroner sinüse yerleştirilir. Elektrofizyoloji kateteri üzerinden guiding kateter veya kılıf kaydırılır ve koroner sinüse yerleştirilir. $\mathrm{Bu}$ yöntemde sıklıkla bükülebilen elektrofizyoloji kateteri (koroner sinüs kateteri veya ablasyon kateteri) kullanılsa da, fixed curve koroner sinüs kateteri de kullanılabilmektedir. Yine bu amaçla içerisinde lümeni olan (kontrast madde verilebilmesi amaciyla) bükülebilen elektrofizyoloji kateterleri geliştirilmiştir. $\mathrm{Bu}$ yöntemin avantaj1, elektrofiztoloji kateterinin koroner sinüse girmeyi veya ilerlemeyi zorlaştıran kapak yapısını kolalıkla geçebilmesidir [1, 3, 4].

Farklı çeşit koroner anjiyografi kateterlerinin, guiding kateter veya k1lıf içerisinden teleskopik amaçlı kullanılması genellikle girişimsel kardiyologların tercih ettiği bir yöntemdir (Şekil 8). Bu yöntemde, sağ atriyuma yerleştirilen guiding kateter içerisine farklı aç1l anjiografik kateterler (sıkl1kla AL2, AL3, multipurpose) yerleştirilir. Sol anterior oblik pozisyondan farklı manevralar uygulayarak (genellikle saat yönünün ters yönüne çevirme) koroner sinüs ağzına yerleşilmeye çalışılır. Kontrast madde verilerek koroner sinüs ağzına yerleşip yerleşmediğini kontrol edilir. Koroner sinüs ağzına yerleşilmesi durumunda, ya guiding kateter anjiyografik kateter üzerine kaydırılarak, ya da guiding kateteri taşıyabilecek bir telin anjiyografi kateteri içerisinden koroner sinüse yerleştirilmesi ve bunun üzerinden guiding kateter kaydırılması işlemi yapılarak guiding kateter koroner sinüse yerleştirilir [1, 3, 4].

Tarif edilen yöntemlere rağmen koroner sinüs kanulasyonu yapılamadığı durumlarda, yapılmadıysa koroner sinüsün antegrad anjiyografi yöntemi ile görüntülenmesi veya femoral ven yolu ile kanüle edilmeye çalışılması böylece koroner sinüs ağız kısmının belirlenmesi yöntemi uygulanabilir. 

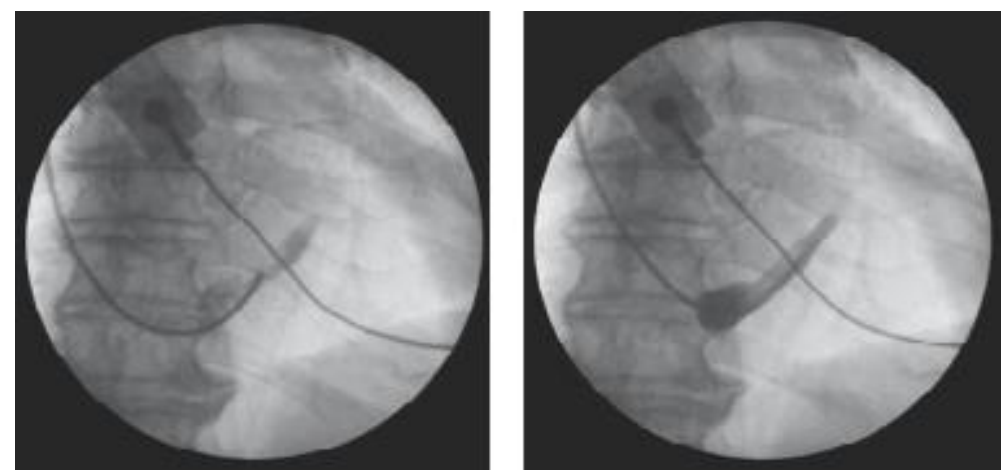

Şekil 6. Koroner sinüsün guiding kateter veya kılıf ile direkt kanülasyonu. Önce guiding kateterin koroner sinüs ostiuma yerleşip yerleşmediği az kontrast madde ile kontrol edildikten sonra (soldaki şekil), guiding kateterin curve kısmı iyice koroner sinüse yerleştirilmesi ve az kontrast madde verilerek poziyonunun kontrol edilmesi (sağdaki şekil).
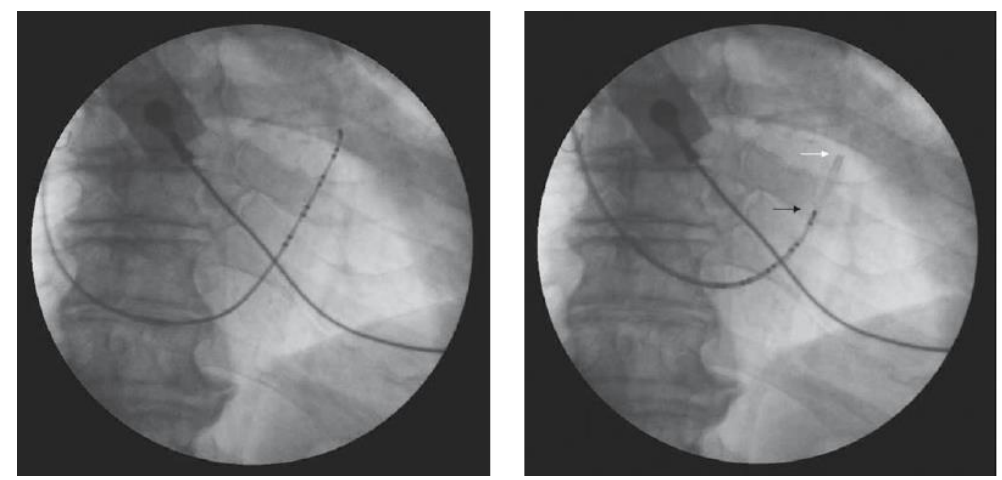

Şekil 7. Bükülebilen (deflectable) elektrofizyoloji kateteri yardımı ile koroner sinüs guiding kateterin koroner sinüse yerleştirimesi. Önce bükülebilen 10 elektrodlu koroner sinüs kateterinin koroner sinüse yerleștirilmesi (solda), sonra guiding kateterin elektrofizyoloji kateteri üzerinde kardırılarak koroner sinüse yerleştirilmesi (sağda).

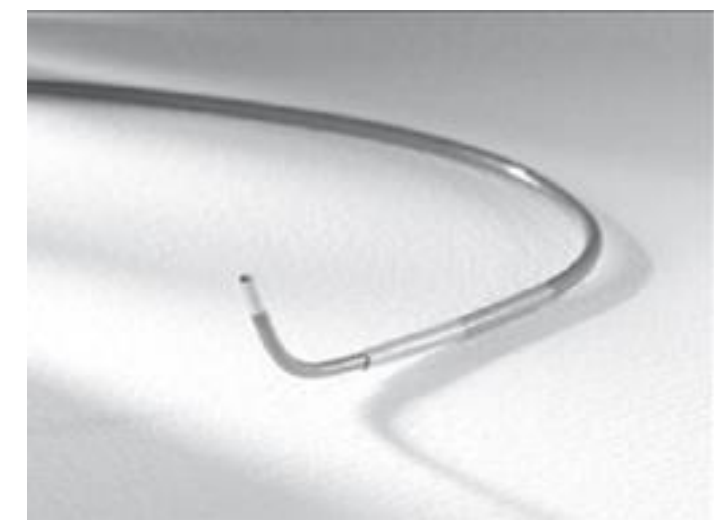

Şekil 8. Koroner sinüs kanülasyonu için guiding kateter içerisinden anjiyografik kateter kullanma yöntemi.

\section{Koroner sinüs görüntülenmesi}

a) Koroner sinüs antegrad anjiografisi

Koroner sinüsün koroner anjiyografi sırasında görüntülenmesi eskiden beri bilinen bir yöntemdir [5-8]. Buna koroner sinüsün antegrad anjiyografisi veya koroner hiperemik venöz dönüş anjiyografisi denmektedir. Koroner arterlerin 6-10 mL kontrast madde verilerek görüntülenmesi sonrasında çekim süresi 5-10 sn. uzatılır, verilen kontrast 
maddenin koroner venöz sistemden sağ atriyuma boşaldığ 1 gözlenir, böylece koroner sinüs sistemi ve dalları gözlenir (Şekil 9). Sol ventrikül elektrodu için hedef dal olup olmadığı saptanır. Ayrıca koroner sinüs kanülasyonu için sağ atriyumda koroner sinüs ağzı belirlenir. İmplantasyondan önce yapılması işlem süresini kısaltmakta ve başarı oranını artırmaktadır [5-8]. Sol veya sağ koroner sistemden ayrı görüntüleme yapılabilir. Fakat sağ koroner sisteme fazla aritmi ihtimali nedeniyle bir anda fazla opak vermekten kaçınılmalıdır. $\mathrm{Bu}$ görüntüleme yönteminin dezavantajı eğer implantasyon sırasında yapılmışsa kullanılan kontrast madde miktarını artırmasıdır.

b) Koroner sinüs venografisi- koroner sinüs retrograd anjiografisi

Koroner sinüs kanülasyonu sonrası koroner sinüsün guiding kateter içerisinden verilen kontrast madde ile görüntülenmesi işlemine koroner sinüs retrograd anjiografisi denmektedir (Şekil 3). İşlem sırasında kontrast madde akıma karşı verildiğinden daha iyi görüntüleme yapmak için koroner sinüs oklüzyon balonu da kullanılmaktadır (Şekil 10) [1, 3-5]. Venöz oklüzyon balonu koroner sinüste disseksiyona neden olabileceğinden dolayı gerekmedikte kullanılmamaktadır. Yarı yarıya serum fizyolojik ile sulandırılmış kontrast maddenin güçlü enjeksiyonu ile yeterli görüntü elde edilebilmektedir. Hedef dal saptandıktan sonra gereksiz görüntülenmeden kaçınılmalıdır. Hedef dal saptanmadığı durumlarda hedef bölgeye diğer dallardan kollateral olup olmadığını saptamak için iç (inner) kateter ile selktif kanülasyon ve kontrast madde ile görüntüleme uygulanabilir. Veya venöz oklüzyon kateteri kollateral aranan dalın gerisinde şişirilerek kontrast madde ile görüntüleme yapılabilir.
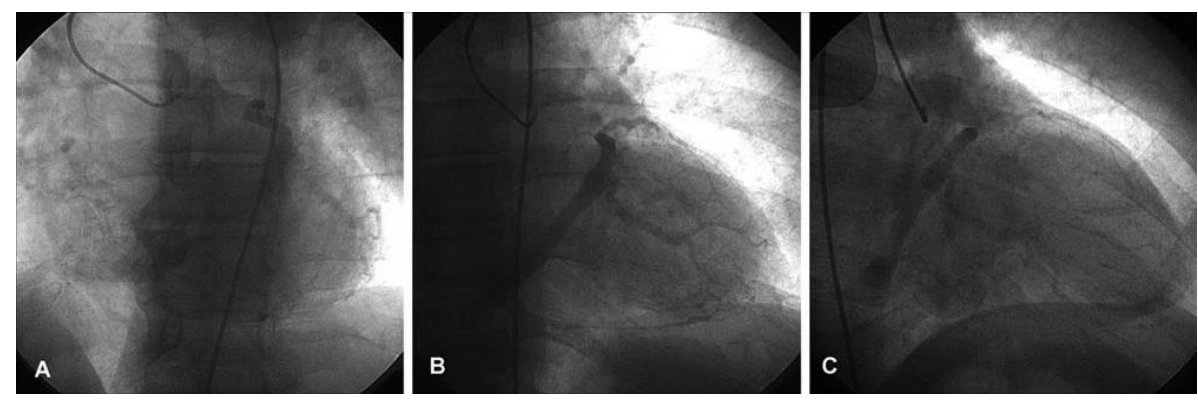

Şekil 9. Koroner sinüsün antegrad anjiografisi. Sol anterior oblik pozisyondan (solda), anterior-posterior pozisyondan (ortada), sağ anterior oblik pozisyondan (sağda).
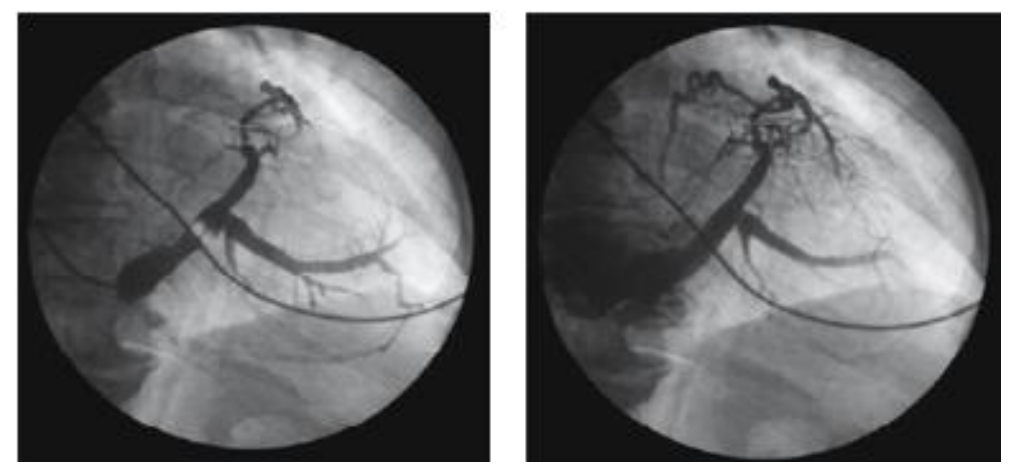

Şekil 10. Koroner sinüsün retrograd anjiografisi. Venöz oklüzyon balonu kullanılarak yapılan retrograd anjiyografi (solda) ile guiding kateter içerisinden güçlü enjeksiyon ile yapılan retrograd anjiyografi (sağda) arasında koroner sinüs ve dallarının görüntülenmesinde anlamlı fark izlenmemektedir.

c) Koroner sinüs CT ve MR görüntülenmesi

İşlem öncesi sol ventrikül elektrodu için hedef dalın varlığını sorgulamak, koroner sinüsün sağ atriyuma açıldığı yeri belirlemek ve ayrıca koroner sinüsün yapısı ve dallarında varsa darlıkların tesbiti açısından işlem öncesi invaziv olmayan bir yöntem kullanılmasının işlem başarısını olumlu etkilediği gösterilmiştir. Bununla ilgili özellikle çok kesitli CT ve MR ile başarılı görüntüleme elde edilmiştir $[9,10]$. 


\section{Sol ventrikül elektrodu yerleştirme teknikleri}

KRT tedavisinden optimal hemodinamik ve klinik faydanın görülmesi için sol ventrikül elektrodunun sol ventrikülün midlateral bölgesindeki koroner venlere yerleştirilmesi önerilmektedir (Şekil 11) [11]. Sol ventrikül elektrodu için optimal pacing bölgesi midlateral bölge olarak kabul edilmektedir $[1,3,4,11]$ Bazı klinik çalışmalarda optimal bölge ile optimal olmayan bölge arasında klinik ve hemodinamik fark saptanmasa da birçok çalışmada KRT tedavisinden fayda görmeme kriterleri arasında sol ventrikül elektrodunun optimal bölge dışındaki bir bölgeye yerleştirilmesi gösterilmiştir [12].

Guiding kateter koroner sinüse yerleştikten ve anjiografi yapılıp hedef dal belirlendikten sonra sol ventrikül elektrodu guiding kateter içerisinden hedef dala 2 şekilde ilerletilebilir. Birincisi, hedef dala 0,014 inc guidewire gönderilmesi ve guidewire üzerinden (over-the-wire) sol ventrikül elektrodu hedef dala gönderilmesi tekniğidir (en sık kullanılan yöntem). İkincisi, sol ventrikül elektrodu içerisine stylet yerleştirilerek hedef dala yönlendirilmeye çalışılması tekniğidir (Şekil 12). Over-the-wire yöntemde hedef damarın koroner sinüsten çıkış açısına, tortuöz yapısına bakılarak farklı sertlikte 0,014 inç teller seçilebilir. Benzer şekilde stylet yönteminde de farklı sertlikte stylet seçilebilir[ $1,3,4,11]$.

Hedef dal içerisinde arzu edilen ölçümler (Eşik $<2 \mathrm{~V}$, R dalgası $>5,0 \mathrm{mV}$, yüksek voltajda diafragma stimülasyonunun olmaması) elde edilene kadar sol ventrikül elektrodu ileri geri hareket ettirilerek yerleştirilir [1].

Sol ventrikül elektrodunun yerleştirildikten sonra yerinden oynamaması için hedef dala yerleştirilen sol ventrikül elektrodunun doğru şeçilmesi gerekmektedir. Büyük bir dal ise French ölçüsü olarak büyük bir elektrod seçilmelidir. Hedef dal küçük veya büyük olsun içerisindeki stylet veya guidewire çıkarıldığı zaman kıvrıntılı şekil alarak dal duvarına birkaç noktadan dayanan elektrodlar tercih edilmelidir. Çok büyük damarlar için geliştirilmiş özel fiksasyon sistemli elektrodlar bulunmaktadır (Şekil 13) $[1,3,4,11]$.

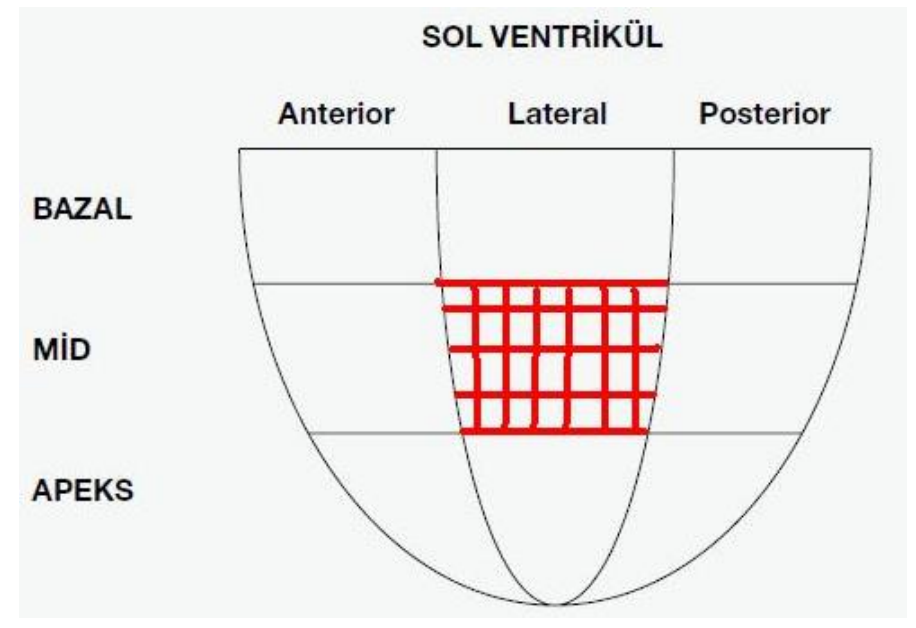

Şekil 11. Sol ventrikül elektrodunun implantasyon bölgeleri. Sol ventrikül elektrodu için optimal hemodinamik ve klinik yarar için önerilen implantasyon bölgesi lateral duvarın mid kısmıdır (kırmızı kareli alan). 

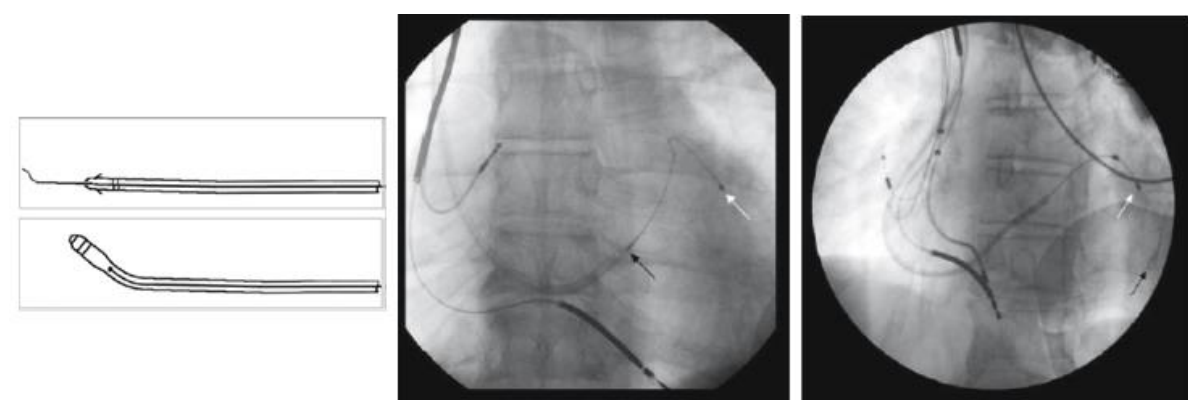

Şekil 12. Sol ventrikül elektrodu implantasyon yöntemleri. Sol ventrikül elektrodunun over the wire yerleştirilmesi tekniği (sol üst ve sağ), sol ventrikül eletrodunun stylet ile yerleştirlmesi tekniği (sol alt ve orta).

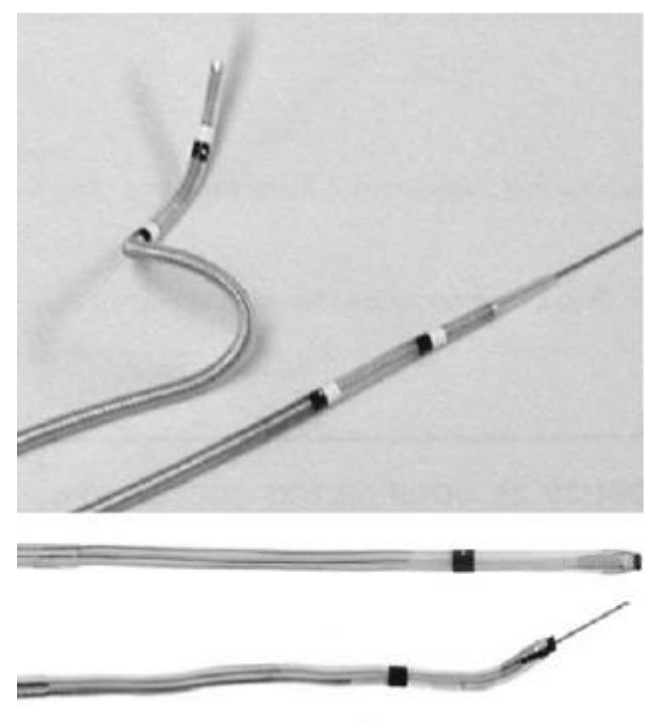

Large vein

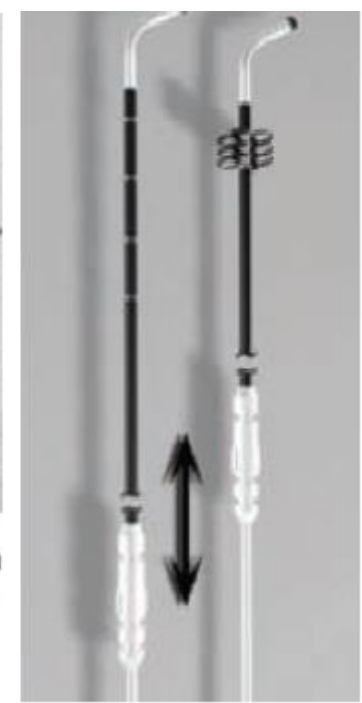

Pericardium

Epicardium

Small vein

Şekil 13. Sol ventrikül elektrod çeşitler. İçerisinde stylet veya guidewire olduğunda düzleşen böylece hedef dala yerleştirilebilen, guidewire veya stylet çıkartıldığında kendiliğinden kıvrılarak (sol üst) gerek küçük gerekse büyük damara daha iyi tutunmayı sağlayan kendiliğinden kıvrık elektrodlar (alt), çok büyük damarlar için geliştirilmiş fiksasyon sistemli elektrodlar (sağ üst).

\section{Sol ventrikül elektrodunun yerleştirilmesinde girişimsel yöntemler}

Sol ventrikül elektrodunun implante edileceği hedef dalda saptanan implantasyonu engelleyen veya implante edildikten sonra stabilizasyonu zorlaştıran durumlarda koroner arterlerdeki birtakım girişimsel yöntemler koroner sinüsde de uygulanabilmektedir (Şekil 14). Hedef dalda darlık varlığında koroner PTCA balon ile darlık genişletilmeye çalışılır. Fakat elektrod ilerletilemiyorsa darlığa elektrod kalınlığından büyük stent implante edilerek stent içinden elektrod hedef bölgeye ilerletilebilir. Hedef dalın koroner sinüse uygunsuz bir açı ile döküldüğü durumlarda double-wire (body wire) tekniği kullanılarak elektrod hedef dala ilerletilebilir. Sol ventrikül elektrodunun tutunamağı geri geldiği büyük hedef dala elektrodu hedef damar ile stent arasına şıkıştıracak şekilde hedef damarın koroner sinüse dökülen proksimal bölümüne kısa stent konulabilir. Ayrıca elektrod geçişine izin vermeyen kapak yapısına sahip koroner sinüse balon dilatasyon uygulanabilmektedir $[1,3,4,11]$. 
TORTUOSITY

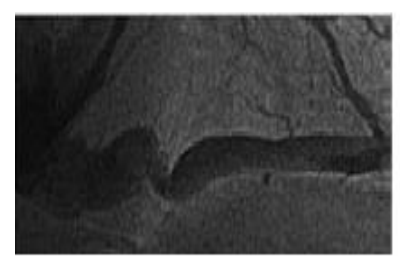

ANGULATION

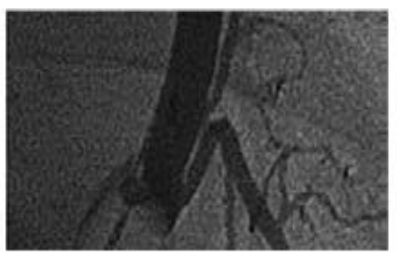

SIZE

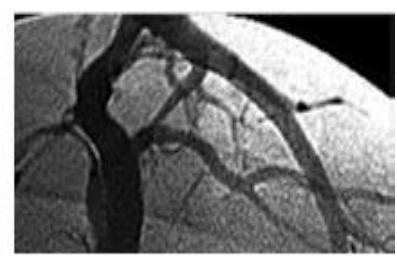

Şekil 14. Sol ventrikül elektrodu için uygunsuz hedef dal örnekleri. Tortüozite varlığında double wire (body wire) veya stent uygulanabilir. Angulasyon varlığında double wire (body wire) tekniği, çok büyük hedef damar varlığında özel fiksasyonlu elektrodlar veya dalın koroner sinüse açılan bölümüne elektrodu sıkıştıracak şekilde stent implantasyonu uygulanabilir.

\section{Sol ventrikül elektrodu yerleştirilmesinde alternatif yöntemler}

Perkütan transvenöz yöntem ile koroner sinüste hedef dal olmaması durumunda hedef bölgenin pace edilebilmesi için alternatif yöntemler uygulanmaktadır (Şekil 15). Bunların en sık uygulananı cerrahi yöntemdir. Minitorakotomi ile sol ventrikül elektrodu epikardiyal olarak yerleştirilebilmektedir. Son yıllarda bu işlem robotik cerrahi ile yapılmaktadır. Diğer bir yöntem ise transeptal ponksiyon yolu ile sol ventrikül elektrodunun sol ventrikül lateral duvarına aktif fiksasyonudur. Oldukça zahmetli bir yöntem olmakla birlikle embolik komplikasyon riskinin yüksek olması nedeniyle INR yüksek $(3,5-4,0)$ tutulması gerekmektedir. Kalp yetmezliği hastalarında cerrahi riskinin yüksek olması nedeniyle videoperikardioskopik yöntem ile perkütan epikardiyal sol ventrikül elektrodu yerleştirilmesi yöntemi de son yıllarda üzerine çalışılan alternatif bir yöntemdir [13, 14].
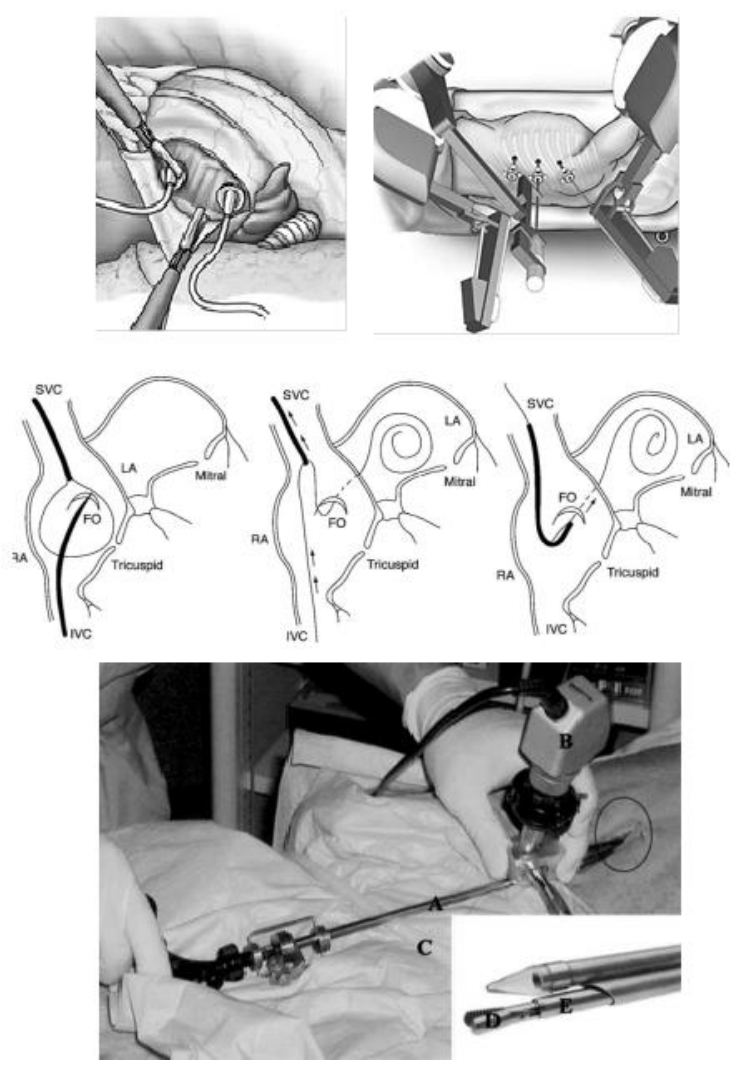

Şekil 15. Sol ventrikül eletrodu implantasyonunda alternatif yöntemler. Minitorakotomi ile epikardiyal implantasyon (sol üstte), robotik cerrahi ile implantasyon (sağ üstte), transseptal ponksiyon yolu ile yerleşim (ortada), perkütan ksifoid yaklaşım ile perikardiyoskopik implantasyon (altta). 


\section{Kaynaklar}

1. Stellbrink C, Breithardt OA, Hanrath P. Technical considerations in implanting left ventricular pacing leads for cardiac resynchronization therapy. Eur Heart J 2004; 6: 42-6.

2. Asirvatham SJ. Anatomy of the coronary sinus. In: Yu CM, Hayes DL, Auricchio A, eds. Cardiac resynchronization therapy, 2nd ed. Oxford: Blackwell Publishing;2008; 166-82.

3. Sweeney MO. Implantation techniques in cardiac resynchronization therapy. In: Yu CM, Hayes DL, Auricchio A, eds. Cardiac resynchronization therapy, 2nd ed. Oxford: Blackwell Publishing;2008; 196-238.

4. Casella M, Russo AD. Biventricular pacemaker and implantable cardioverterdefibrillator implantation. In: Casella M, Russo AD, eds. An atlas of radioscopic catheter placement for the electrophysiologist, 1st ed. London: Springer-Verlag Ltd 2008; 235-64.

5. Singh JP, Auricchio A. Techniques for visualizing the coronary sinus and coronary venous anatomy. In: Yu CM, Hayes DL, Auricchio A, eds. Cardiac resynchronization therapy, 2nd ed. Oxford: Blackwell Publishing 2008; 183-95.

6. Gilard M, Mansourati J, Etienne Y. Angiographic anatomy of the coronary sinus and its tributaries. Pacing Clin Electrophysiol 1998; 21: 2280-4.

7. Delarche N, Bader H, Lasserre R. Importance of anterograde visualization of the coronary venous network by selective left coronary angiography prior to resynchronization. Pacing Clin Electrophysiol 2007; 30: 70-6.

8. Arbelo E, García-Quintana A, Caballero E. Usefulness of hyperemic venous return angiography for studying coronary venous anatomy prior to cardiac resynchronization deviceimplantation. Rev Esp Cardiol 2008; 61: 936-44.

9. Malagò R, Pezzato A, Barbiani C. Non invasive cardiac vein mapping: role of multislice CT coronary angiography. Eur J Radiol 2012; 81: 3262-9.

10. Younger JF, Plein S, Crean A, Ball SG, Greenwood JP. Visualization of coronary venous anatomy by cardiovascular magnetic resonance. J Cardiovasc Magn Reson 2009; 11: 26.

11. Cazeau S, Ritter P, Lazarus A. Multisite pacing for end-stage heart failure: early experience. Pacing Clin Electrophysiol 1996; 19: 1748-57.

12. Mortensen PT, Herre JM, Chung ES. The effect of left ventricular pacing site on cardiac resynchronization therapy outcome and mortality: The results of a PROSPECT substudy. Europace 2010; 12: 1750-6.

13. Bailey S, Wilkoff BL. Alternative techniques for left ventricular lead placement. In: Barold SS, Ritter P, eds. Devices for cardiac resynchronization: Techniques and cinical aspects, 1st ed. New York: Springer Science Bussiness Media LLC 2008; 17-26.

14. Whinnett Z, Bordachar P. The risks and benefits of transseptal endocardial pacing. Curr Opin Cardiol 2012; 27: 19-23. 